\title{
Exogenous testosterone does not modulate aggression in sex-role-reversed female Barred Buttonquails, Turnix suscitator
}

\author{
Christina Muck $^{1} \mathbb{D} \cdot$ Wolfgang Goymann ${ }^{1}$
}

Received: 20 April 2018 / Revised: 22 November 2018 / Accepted: 29 November 2018 / Published online: 11 December 2018

(c) The Author(s) 2018

\begin{abstract}
In sex-role-reversed species, females are typically the more competitive sex, defending territories and access to mates, while males take care of the young, often without any help from the female. In males of species with traditional sex roles, testosterone levels generally rise during the breeding season and modulate territorial and aggressive behaviour. Similarly, testosterone may modulate aggressive behaviour in females of sex-role-reversed species. To test this idea, we experimentally increased testosterone levels in sex-role-reversed polyandrous female Barred Buttonquails (Turnix suscitator) by implanting them with testosterone pellets and testing their behavioural responses during a simulated territorial challenge. Contrary to expectations, the testosterone treatment did not elicit a stronger aggressive response towards a simulated intruder than in control females. Furthermore, testosterone levels of control females were not elevated during the challenge, and were actually lower after the challenge than before it. Our study did not find any evidence that exogenous testosterone increases aggression in female Barred Buttonquails.
\end{abstract}

Keywords Androgens $\cdot$ Agonistic behaviour $\cdot$ Classical polyandry $\cdot$ Simulated territorial intrusion $\cdot$ Intra-sexual competition $\cdot$ Female

\section{Zusammenfassung}

Experimentell erhöhtes Testosteron zeigt keine Wirkung auf territoriale Aggression bei weiblichen Bindenlaufhühnchen, Turnix suscitator

Weibchen von polyandrischen Arten, bei denen die typischen Geschlechterrollen vertauscht sind, konkurrieren meist stärker um Territorien und Paarungsmöglichkeiten als die Männchen. Diese widerum kümmern sich hauptsächlich um Brut und Aufzucht der Jungen, häufig sogar ganz ohne die Hilfe der Weibchen. Männchen von Arten mit traditionellen Geschlechterrollen zeigen während der Brutzeit erhöhte Testosteronwerte, die territoriales Verhalten und Aggression bestimmen. Auf eine ähnliche Weise könnte Testosteron auch territoriales Verhalten bei Weibchen polyandrischer Arten beeinflussen. Um diese Idee zu testen, haben wir polyandrischen Bindenlaufhühnchen-Weibchen (Turnix suscitator) Testosteronpellets subcutinan implantiert, um somit die Testosteronkonzentration im Blut zu erhöhen, und dann ihr Verhalten während eines simulierten Territoriumübergriffs mit einer Bindenlaufhühnchenatrappe analysiert. Entgegen unseren Erwartungen hat die Testosteronbehandlung bei Weibchen der Experimentalgruppe keine stärkere Aggression gegenüber dem simulierten Eindringling hervorgerufen als bei Weibchen der Kontrollgruppe beobachtet wurde. Ausserdem hatten Kontrollweibchen nicht wie erwartet erhöhte sondern niedrigere Testosteronwerte, nachdem sie dem simulierten Territoriumsübergriff ausgesetzt waren. Unsere Studie konnte demnach keinen Hinweis liefern, dass experimentell erhöhtes Testosteron territoriale Aggression bei weiblichen Bindenlaufhühnchen steigert.

Communicated by L. Fusani.

Christina Muck

muck@ orn.mpg.de

Wolfgang Goymann goymann@orn.mpg.de
1 Department of Behavioural Neurobiology, Max Planck Institute for Ornithology, Eberhard-Gwinner-Straße, 82319 Seewiesen, Germany 


\section{Introduction}

In sex-role-reversed species, females typically establish and vigorously defend breeding or feeding territories, and show stronger intra-sexual competition for mates than males (Clutton-Brock and Vincent 1991). The males of these species, on the contrary, take care of the young, often without any help from the females (Clutton-Brock and Vincent 1991). Such a reversal of the classic sex roles occurs only in a small fraction of bird species $(<1 \%)$, and only little is currently known regarding the physiological control mechanisms of this rare breeding system (Andersson 1995; Owens 2002; Voigt and Goymann 2007; Goymann et al. 2008; Voigt 2016).

In bird species with conventional sex roles, in which mainly males compete over access to resources and mates, sexual differentiation of brain and behaviour is generally (but not solely) dependent on gonadal steroid hormones (Arnold and Gorski 1984; Ball and Balthazart 2008). Androgens and oestrogens act via their corresponding hormone receptors to first organize the development of sexually differentiated brain areas and-later on-to activate the corresponding male and female behaviours [McEwen et al. 1979; Arnold and Gorski 1984; but see Zhao et al. (2010) for hormoneindependent effects]. For example, in many bird species, the level of the androgen testosterone is typically higher in males than in females, and during the breeding season male testosterone levels rise, activating and modulating courtship and agonistic behaviour (reviewed by Wingfield et al. 2006). Later in the breeding season, testosterone levels decrease to their baseline levels, as do courtship and territorial aggression (Balthazart 1983; Wingfield and Farner 1993; Wingfield et al. 2006). Moreover, experimentally elevated testosterone levels in males can lead to an increase in territorial aggression (Soma 2006; Wingfield et al. 2006), while a simulated territorial intrusion can cause an increase in circulating testosterone levels in males (Wingfield 1985; Wingfield and Wada 1989, but see Goymann 2009).

In females, circulating testosterone levels are generally lower than in males, but they also vary over the course of the annual cycle, with higher concentrations observed just before or during the breeding season (e.g. Elekonich and Wingfield 2000; Ketterson et al. 2005). Furthermore, in females of some bird species, testosterone levels are related to aggression during breeding (e.g. mate and resource defence), indicating the potential role of testosterone as a modulator of behaviour also in this sex (Staub and DeBeer 1997; Wingfield et al. 2000; Ketterson et al. 2005; Sandell 2007; Rosvall 2013). This relationship, however, is still much debated (e.g. Goymann and Wingfield 2014) because other studies could not find an association between testosterone and aggression (e.g. Jawor et al. 2006 and references therein). Moreover, high levels of testosterone may bear major costs for females, such as a reduction in ovulation, incubation, hatching success and immune function (Ketterson et al. 2005; Zysling et al. 2006; Veiga and Polo 2008; Rosvall 2013), possibly favouring alternative mechanisms for the modulation of aggression. For example, females may regulate testosterone-linked behaviour via the sensitivity of certain brain areas to this hormone (Voigt and Goymann 2007; Voigt 2016), in which case, females would not need high levels of testosterone to modulate traits that are typically expressed by breeding males (Goymann and Wingfield 2014; Voigt and Goymann 2007; Voigt 2016).

Similarly, sex-role reversal does not simply indicate reversed circulating testosterone concentrations (i.e. with females expressing high levels and males expressing low levels of testosterone). Both females and males of sex-rolereversed species studied so far generally showed levels of testosterone comparable to those of species with conventional sex roles (e.g. Rissman and Wingfield 1984; Fivizzani and Oring 1986; Schlinger et al. 1989; Goymann and Wingfield 2004). Hence, even in species where females are clearly the more aggressive sex, and in which females may not face a testosterone-mediated trade-off between mating and parental care (i.e. as described in Rosvall 2013), testosterone may act differently in females than in males (Goymann and Wingfield 2014). Reversed sexual dimorphism in testosterone-dependent behaviour and other traits may be generated by a more pronounced expression of androgen receptors in brain areas involved in agonistic and sexual behaviour in females only, thereby avoiding the need for high testosterone levels in this sex (Voigt and Goymann 2007; Voigt 2016).

In the sex-role-reversed Barred Buttonquail, females express more androgen receptor messenger RNA (mRNA) in brain areas responsible for socio-sexual behaviours than males (Voigt 2016). This female bias in mRNA expression of androgen receptors in the brain is already present in hatchlings, suggesting that in Barred Buttonquails testosterone may indeed play a role in the development and the activation of reversed sex roles (Voigt 2016). Both female and male Barred Buttonquails express low levels of testosterone (typically $<0.3 \mathrm{ng} / \mathrm{ml}$ in both sexes) throughout the year [including both breeding and non-breeding periods (see Voigt 2016)], but unlike all other sex-role-reversed species investigated so far, there is no difference in levels of circulating testosterone between them (Muck and Goymann 2009; Voigt 2016). Moreover, despite low levels of circulating testosterone, body size and condition are positively correlated with testosterone in female Barred Buttonquails. Furthermore, size and darkness of the black throat patch increase with circulating levels of testosterone in this species (Muck and Goymann 2009). In sum, there are indications that testosterone may play a more prominent role in the regulation of sex-role-reversed traits in 
Barred Buttonquails than in other sex-role-reversed species. To further investigate the importance of testosterone in this species' sex-role-reversed traits-specifically its role in aggression during female-female competitionwe manipulated testosterone concentrations of females and studied the effect of this on female territorial behaviour. To achieve this, we implanted testosterone pellets in captive female Barred Buttonquails and tested their behavioural response during a simulated territorial intrusion using a female decoy. We also measured testosterone levels in control females before and after the simulated territorial challenge to identify corresponding changes in hormone levels. We predicted that testosterone-implanted females would react more aggressively towards an intruder than control females with sham implants. Furthermore, we predicted that the territorial challenge would increase testosterone levels in control females.

\section{Methods}

\section{Study species and housing}

Barred Buttonquails are socially polyandrous, with females aggressively defending territories and vocalising to deter rivals and attract males. Males mainly incubate the eggs and care for the hatched young (Trollope 1970; Ridley 1978; Debus 1996). This species has a marked reversed sexual size dimorphism (Starck 1991; Debus 1996), and only females have a black throat patch throughout the year (Sutter 1955; Starck 1991).

We investigated the behaviour and hormone levels of 12 female Barred Buttonquails housed at the Max Planck Institute for Ornithology in Seewiesen, Germany, between 2008 and 2009. Nine of these females were obtained from a breeder in the Netherlands, and the three other females were raised amongst the breeding stock of the Max Planck Institute for Ornithology, Germany. All of these females were kept in female-male pairs, and were 1-3 years old during the study.

All the female-male pairs were kept in indoor boxes made from opaque polypropylene $(1.0 \mathrm{~m} \times 1.0 \mathrm{~m} \times 0.7 \mathrm{~m})$ under a light-dark schedule of 13:11 h, mimicking conditions similar to those of this species' equatorial origin. The boxes were equipped with grass tussocks, artificial plants and little haystacks to offer hiding and nesting areas. Food and water were provided ad libitum. The top of the boxes was covered with a net so that the birds could not escape, or hurt themselves when jumping and fluttering inside the boxes. All birds were naïve to the experimental procedures and had not been used for previous experiments.
Barred Buttonquails do not have a defined breeding period; they reproduce throughout the year if conditions are favourable for breeding (Hoesch 1960; Starck 1991). Also, Barred Buttonquails do not have a specific period of molting (Sutter 1955; Muck, personal observations), and show little variation in circulating testosterone levels over the year (Muck and Goymann 2009). We therefore did not schedule our experiment for a defined season.

\section{Experimental setup}

Females and their male partners were introduced into their cages at least 42 days prior to the experiment to let the birds adjust to both the environmental conditions and their social mate (mean: $47 \pm 2.8$ days, range $42-73$ days). The 12 cages were placed in two separate rooms with six cages per room. Adjacent pairs could hear but not see each other. Furthermore, the birds could only hear, but not see, the person preparing and conducting the experiment.

The 12 females were randomly divided into two groups (irrespective of the room in which they were housed). Six females were given a testosterone implant (see below), while the other six females received a sham (control) implant. We took the first blood sample of each bird 1-3 weeks prior to testosterone implantation to determine baseline testosterone concentrations, and measured body mass to the nearest $0.1 \mathrm{~g}$. Two days after implantation, we took another blood sample to determine the actual increase in the circulating testosterone concentration elicited by the implant. Four days after implantation, we simulated a territorial intrusion of $20 \mathrm{~min}$, after which we immediately caught the birds for a final blood sample to determine post-challenge levels of testosterone.

For the simulated territorial intrusion, we placed a stuffed female decoy in the centre of the cage and played back Barred Buttonquail song (20 s of booming repeated every minute) using a mini-disc player with a Pignose portable loudspeaker situated outside the box right next to one of its side walls. For each female, we used the same decoy and played back the same song recording, which was a deep resonant booming call that females produce to attract males and to deter other females (Debus 1996). Females typically respond aggressively to another female that is booming in or near their territory (Debus 1996). We are aware that this setup caused a potential problem of pseudoreplication, but we had only access to one decoy, and limited high-quality recordings of buttonquail vocalizations. [In other bird species such as Great Tits (Parus major), the use of different decoys did not explain any variance in aggressive behaviour (Araya-Ajoy and Dingemanse 2013)]. The behaviour of the focal bird was recorded during the 20-min period that the decoy was present in the cage using a Sony DCRTRV6E digital camera, which was fixed on a tripod standing above, or next to the cages. The camera was placed in this 
respective position approximately $10 \mathrm{~min}$ before the introduction of the decoy; the birds did not show a behavioural response when the camera was installed. Recordings started right after the decoy was introduced into the cage.

We tested two to three birds per day. We ensured that females that were experimentally challenged on the same day were not in neighbouring cages, and we altered the order of tested cages for successive tests between rooms to prevent the disturbance affecting the outcome of the experiment. All tests were done in the morning between 9.00 and 12.00 a.m. The order in which females were challenged (i.e. first, second or third on the same day) mirrored the time at which the birds were challenged (i.e. the first one at 9.00 a.m., the second one at 10 a.m., the third one at 11 a.m.); the timing/order of testing did not significantly affect the behaviour or hormone levels of the tested birds (Kruskal-Wallis $t$-test, $d f=2$; approach, $X^{2}=3.90, p=0.35$; jump, $X^{2}=0.31$, $p=0.92$; hide, $X^{2}=0.73, p=0.74$; pace, $X^{2}=5.31, p=0.06$; freeze, $X^{2}=0.44, p=0.83$; latency, $X^{2}=1.05, p=0.63$; testosterone, $X^{2}=2.31, p=0.35$ ).

\section{Hormone implantation}

Subcutaneous implantation of testosterone was authorised by the government of Upper Bayern, Germany, in June 2008 (55.2-1-54-2531-31-08). Females were implanted with timerelease pellets (Innovative Research of America; Sarasota, FL). The testosterone dosage was $1 \mathrm{mg}$ testosterone/pellet. The pellets were designed to release the hormone at $0.05 \mathrm{mg} /$ day to give a constant testosterone level for 21 days. Control birds received empty placebo pellets of the same size. The pellets were implanted subcutaneously by inserting them through a small incision in the skin on each bird's back between the scapulas. The incision was sealed with tissue glue (Histoacryl; Braun Surgical). The whole procedure took about $2 \mathrm{~min}$, and the birds were released into their boxes after the incision had been closed and the birds were alert.

\section{Behavioural measures}

Videos were analysed using the program JWatcher 0.9 (2000). During video analysis the observer was blind regarding whether the focal female belonged to the control or the testosterone-implanted group. We recorded the duration of the following behaviours shown by the focal female: (1) latency until the first approach towards the decoy (latency); (2) immobility (freezing behaviour); (3) hiding behind a grass tussock (hiding); (4) repeated meandering back and forth next to the wall of the cage (pacing); and also recorded (5) how often the bird approached the decoy to a distance of at least $10 \mathrm{~cm}$ (approach); (6) how often the bird physically attacked the decoy (attack); (7) how often the bird called; and (8) how often the bird jumped vertically, occasionally with simultaneous rapid wing movements (flight-jump).

\section{Blood samples}

Blood samples $(150-200 \mu \mathrm{l})$ were taken from the alar wing vein within $2.4 \pm 0.06 \mathrm{~min}$ (range 1.02-2.48 min) of opening a cage to capture a bird. We used syringe needles (0.6$\mathrm{mm}$ diameter) to pierce the vein and collected the blood using heparinised capillary tubes. The plasma was immediately separated from the blood sample (centrifuged at 10,000 r.p.m. for $15 \mathrm{~min}$ ) and stored at $-80{ }^{\circ} \mathrm{C}$ until the hormone assays were completed.

\section{Hormone analysis}

Testosterone was analysed using a radioimmunoassay as described by Goymann et al. (2006). We conducted four separate assays to analyse all samples. The mean extraction efficiency was $90 \pm 4 \%$, the mean intra- and inter-assay coefficients of variation were $8.8 \%$ and $8.4 \%$, respectively, and the detection limit (mean $\pm \mathrm{SD}$ ) was $0.40 \pm 0.08 \mathrm{pg} /$ tube . Because the testosterone antibody used showed some crossreactivity (44\%) with dihydrotestosterone, our measurements may include a minor fraction of this other potent androgen.

\section{Statistical analysis}

Statistical analyses were conducted using SPSS 15.0. Values are expressed as mean \pm SEM and the statistical significance was set at $\alpha \leq 0.05$ (two-tailed).

Testosterone data were log transformed to obtain a better model fit. We used a general linear mixed model to compare testosterone levels measured 2 days before and immediately after the experimental challenge, between control and testosterone-implanted females. This model comprised hormone concentration as the dependent variable, experimental group and time of measurement (i.e. before or after the experiment) as fixed factors, bird identifier as a random factor, body mass as a covariate, and the interactions between experimental group and time of measurement. In a separate test, we also analysed testosterone levels before and after the experimental challenge in control females only, using a paired $t$-test.

Behavioural data were not normally distributed, thus differences in behaviour between control females and testosterone-implanted females were analysed non-parametrically using Mann-Whitney $U$-tests.

Because our study was based on a relative small sample size, we conducted a sensitivity analysis to assess the validity of our results. We compiled the results of other studies that investigated the effect of exogenous testosterone on female aggression and compared their effect sizes (Cohen's d) with those of our experiment. 
Table 1 Testosterone concentration (mean \pm SEM) of female Barred Buttonquails before implantation (Baseline), after implantation/before the 20-min territorial challenge (Before STI), and after the territorial challenge (After STI), compared between control females and testosterone-implanted females

\begin{tabular}{lcr}
\hline Testosterone $\mathrm{pg} / \mathrm{ml}$ & Control group $(n=6)$ & Experimental group $(n=6)$ \\
\hline Baseline & $178.3 \pm 46.2$ & $161.42 \pm 41.1$ \\
Before STI (after implantation) & $122.88 \pm 21.8$ & $5543.26 \pm 920.4$ \\
After STI & $81.15 \pm 9.2$ & $3024.76 \pm 340.8$ \\
\hline
\end{tabular}

Testosterone-implanted females and control females had similar baseline levels; however, testosterone-implanted females had significantly higher testosterone levels after implantation than control females (general linear mixed model, experimental group, $F_{1,7.43}=31.36, p=0.001$; baseline-challenged group, $F_{1,9.72}=33.82, p<0.001$; interaction, $\left.F_{1,9.72}=80.78, p<0.001\right)$. Plasma testosterone levels of control females significantly decreased after the challenge $(t=3.207, p<0.05)$

STI simulated territorial intrusion

\section{Results}

\section{Plasma testosterone}

Testosterone implants increased the hormone level from ten- to 30-fold in experimental birds compared to baseline levels 3 weeks prior to the implantation and the testosterone levels of control females (Table 1). Accordingly, there was a significant difference in testosterone levels between the experimental group and the control group, and also between baseline levels 3 weeks prior to the experiment and levels of testosterone post-subcutaneous testosterone implantation (general linear mixed model, $F_{1,12.17}=30.21$, $p<0.001, F_{1,10.32}=34.78, p^{<} 0.001$, respectively). The significant interaction between experimental group and time of measurement $\left(F_{1,10.32}=83.10, p<0.001\right)$ indicates that the testosterone levels of testosterone-implanted females significantly increased after implantation, while testosterone levels of control females after implantation were equal to baseline levels (Table 1). Body mass did not significantly affect testosterone levels $\left(F_{1,9.80}=0.003, p=0.96\right)$. Within the control group, though, testosterone levels significantly decreased between the measurement 2 days before and immediately after the simulated territorial intrusion (Table $1 ; t=3.207$, $p<0.05$ ).

\section{Behaviour}

None of the females attacked the decoy, nor did any of the birds call or feed. Therefore, these behaviours were not included in the analyses.

Latency after the start of the territorial challenge did not differ significantly between control and testosterone-implanted females (Table 2; Mann-Whitney $U$-test, $Z=-0.64, p=0.59)$. Similarly, control and testosteroneimplanted females did not differ significantly in the frequencies of flight-jumps $(Z=-1.44, p=0.20)$, approach ( $Z=-0.66, p=0.56)$, freezing $(Z=-0.64, p=0.59)$, pacing $(Z=-0.16, p=0.94)$, or hiding $(Z=-0.64, p=0.59$; Fig. 1).

The sensitivity analysis demonstrates that the minimal effect size that we could have detected with our sample size was 1.58 (Table 3), i.e. if any of the behaviours of testosterone-implanted females had differed from that of control females by a factor of 1.58 we would have been able to demonstrate such an effect given our sample size. The few other studies that investigated the effect of exogenous testosterone on aggressive behaviour in female birds indeed produced effect sizes in the range of 1.5 (with one exception; Table 3). Hence, if testosterone implants had had a similar effect in female buttonquails as in these other species, then our sample would have been sufficient to at least observe a
Table 2 Behaviours shown by testosterone-implanted females and control females towards a simulated intruder during a 20-min challenge

\begin{tabular}{|c|c|c|c|c|c|}
\hline \multirow[t]{2}{*}{ Behaviour } & \multicolumn{2}{|l|}{ Mean \pm SE } & \multirow{2}{*}{$\begin{array}{l}\text { Effect size } \\
\text { Cohen's } d\end{array}$} & \multicolumn{2}{|c|}{$\begin{array}{l}\text { Mann-Whitney } \\
U \text {-test }\end{array}$} \\
\hline & Control $(n=6)$ & STI $(n=6)$ & & $Z$ & $p$ \\
\hline Latency (min) & $3.3 \pm 3.17$ & $4.2 \pm 3.19$ & -0.116 & -0.64 & 0.59 \\
\hline Freezing (min) & $5.4 \pm 2.72$ & $5.6 \pm 2.46$ & -0.031 & -0.16 & 0.94 \\
\hline Hiding (min) & $6.8 \pm 2.93$ & $8.9 \pm 3.16$ & -0.281 & -0.64 & 0.59 \\
\hline Pacing (min) & $5.3 \pm 2.23$ & $4.3 \pm 1.41$ & 0.219 & -0.16 & 0.94 \\
\hline Approaching (frequency) & $2.5 \pm 1.93$ & $2.2 \pm 1.05$ & 0.193 & -0.66 & 0.56 \\
\hline Flight-jump (frequency) & $0.3 \pm 0.33$ & $3.0 \pm 2.41$ & -0.641 & -1.44 & 0.2 \\
\hline
\end{tabular}

Cohen's $d$ for the differences between control and experimental females are also shown 
Fig. 1 Testosterone-implanted females and control females did not differ in behaviours shown towards a simulated intruder during a 20 -min challenge (Mann-Whitney $U$-test, $p>$ 0.2). Error bars show the SEM. Latency, freezing, hiding and pacing are given as total duration (minutes) per territorial challenge; approach and flight jump are given as total number of occurrences per territorial challenge. None of the behaviours differ between control and testosterone-implanted females (Mann-Whitney $U$-test, $p>$ $0.2)$

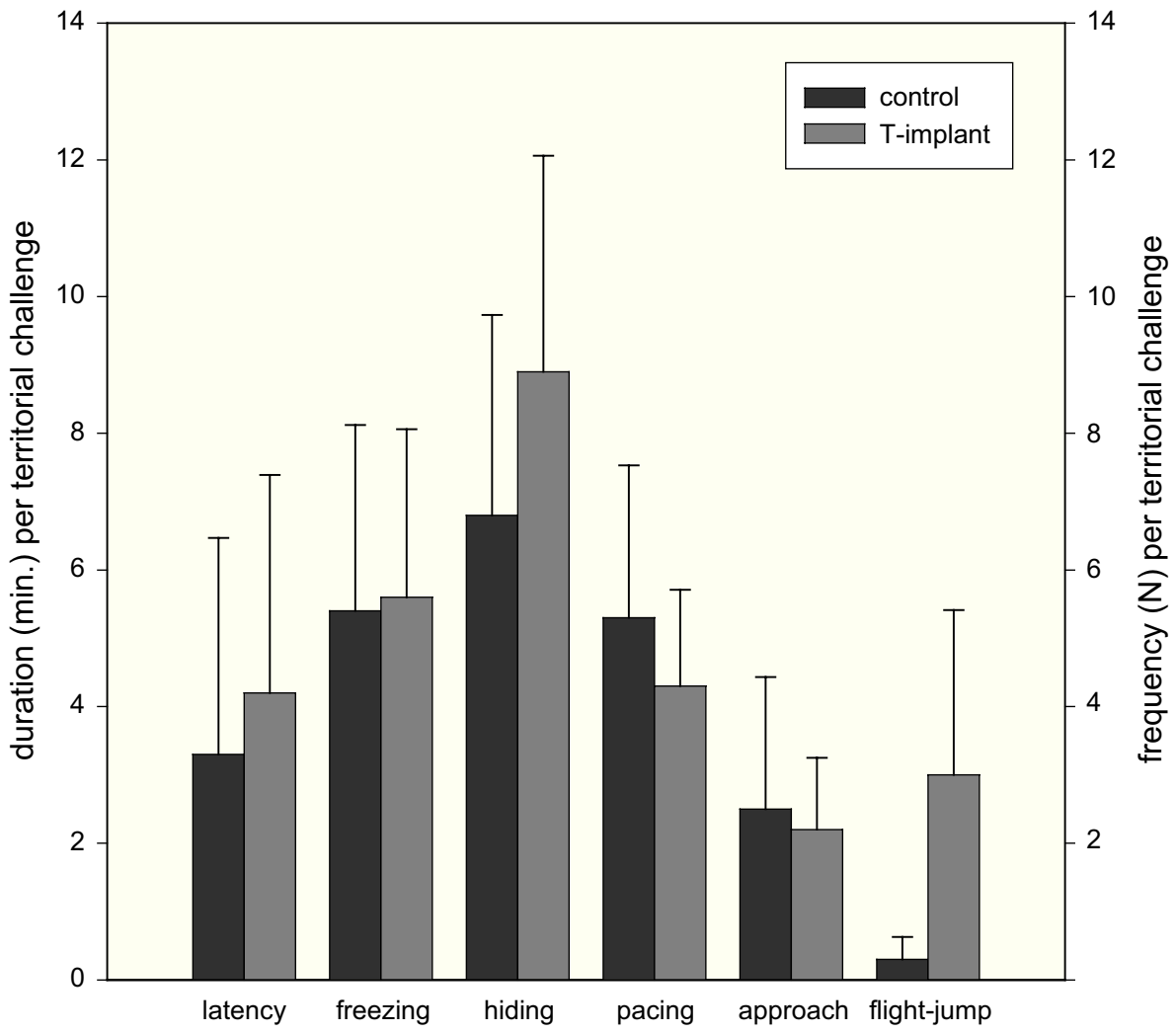

Table 3 Effect sizes of experimental (Exp.) studies investigating the effect of exogenous testosterone on aggressive behaviours in female birds

\begin{tabular}{|c|c|c|c|c|c|c|}
\hline Species & Measures & $p$ & Control $(n)$ & Exp. group $(n)$ & Effect size $(\delta)$ & References \\
\hline $\begin{array}{l}\text { Barred Buttonquail Turnix } \\
\text { suscitator }\end{array}$ & Aggression/fear & $>0.50$ & 6 & 6 & $1.58^{\mathrm{a}}$ & This study \\
\hline $\begin{array}{l}\text { Red-winged Blackbird Agelaius } \\
\text { phoeniceus }\end{array}$ & Aggressive songs & $<0.01$ & 8 & 7 & 1.67 & Searcy (1988) \\
\hline $\begin{array}{l}\text { European Starling Sturnus } \\
\text { vulgaris }\end{array}$ & $\begin{array}{l}\text { Proportion of time spent near } \\
\text { cage/decoy }\end{array}$ & 0.027 & 10 & 10 & 1.79 & Sandell (2007) \\
\hline $\begin{array}{l}\text { Dark-eyed Junco Junco hyemalis } \\
\text { carolinensis }\end{array}$ & Number of aggressive displays & $<0.05$ & 10 & 15 & 0.88 & Zysling et al. (2006) \\
\hline Zebra Finch Taeniopygia guttata & Chasing (aggression) & 0.036 & 9 & 10 & 0.81 & Adkins-Regan (1999) \\
\hline
\end{tabular}

${ }^{\mathrm{a}}$ Measurable effect size estimated from a sensitivity analysis based on our sample size

trend. However, all measured effect sizes (see Table 2) were far lower than 1.58. Also, the effects were not consistent with regard to the direction of the change (i.e. negative and positive values), further suggesting that testosterone had no consistent effect with regards to an increase in any kind of response that could be regarded as aggressive.

\section{Discussion}

In sex-role-reversed female Barred Buttonquails experimentally elevated testosterone levels did not affect the birds' behavioural response during a simulated territorial challenge. Control females with unmanipulated hormone levels and females of the experimental testosterone group approached the decoy with similar latencies, and neither of these groups showed any form of highly aggressive behaviour towards the simulated intruder. However, control females had decreased testosterone levels after the territorial challenge. These results contrast with our prediction that increasing levels of circulating testosterone after testosterone implantation would lead to an increase in aggression of female Barred Buttonquails, and that agonistic interactions would lead to an increase in testosterone levels in control birds. 
Neither females implanted with testosterone nor control females showed systematic differences in behaviours during a 20-min presentation of a female decoy that could be interpreted as a difference in aggression. Independent of their experimental group, most (nine out of 12) females approached the decoy with similar latencies; if anything, testosterone-treated females actually approached the decoy less often and at higher latencies than control females. We therefore presume that artificially elevated testosterone levels did not accelerate a focal bird's approach towards the simulated intruder. Latency of approach as a measure of aggression during simulated intrusions may be unaffected by testosterone, while other territorial behaviours and vocalizations may still be modulated by the hormone within the same species (e.g. Canoine and Gwinner 2002; Schwabl et al. 2005; Apfelbeck et al. 2013). In our study, however, none of the females actually attacked the decoy physically or showed other forms of highly aggressive behaviour such as aggressive postures, pecks or calls. Previous observations of captive female Barred Buttonquails described the birds as aggressive towards their own sex, especially during breeding; they may attack their opponent by pecking the head and neck and by grasping nuptial feathers with the beak (Starck 1991; Debus 1996). Here, however, the decoy did not evoke responses other than restlessness in the female and approaching the decoy. Females of the same breeding stock in Seewiesen kept in similar housing and breeding conditions have previously been shown to perform female-biased agonistic behaviour that only included the chasing of other individuals (Voigt 2016). Approaching a decoy in our experiment could be interpreted as a chasing attempt. Because we did not find differences in any behaviour between control and experimental females, it appears that testosterone may not directly alter the aggressivity of females during a potential territorial challenge.

However, there may have been other reasons for the lack of a highly aggressive response directed towards the decoy. First, it is possible that the female Barred Buttonquails did not experience the decoy as a territorial intrusion, which may explain why they did not respond as expected to the decoy. Instead, females may have perceived the decoy as a novel object and hence shown neophobic behaviours towards it (Scriba and Goymann 2008). The fact that both control and testosterone-treated females showed substantial hiding behaviour supports this possibility. Second, even though all females were housed with a male in their cage for more than 42 days, they may not have perceived the environment as a territory that was worth defending [see Glickman and Caldwell (1994) for an illustrative example in wood rats]. Third, the testosterone treatment unexpectedly resulted in supraphysiological levels of testosterone in experimental females, i.e. the levels of testosterone were substantially higher than those that females experience under normal conditions. This may have been caused by a non-constant release of the hormone by the implanted pellets (see also Fusani 2008; Quispe et al. 2015). It therefore remains speculative whether such high testosterone concentrations could actually trigger a behavioural response, even though most hormone treatments of birds may lead to supra-physiological levels that still elicit expected responses [discussed in more detail by Goymann et al. (2015); Goymann and Dávila (2017)].

Rosvall (2013) found increased levels of aggression in testosterone-treated female Tree Swallows (Tachycineta bicolor). These females were confronted with a live caged female conspecific, though, and not a stuffed decoy. Another study, which compared the responses of free-living European Robins (Erithacus rubecula) to stuffed and live decoys, found that males responded more aggressively towards a stuffed intruder than towards a caged live decoy (Scriba and Goymann 2008). However, these responses are difficult to compare because different species and sexes may respond differently to caged and stuffed decoys, and the responses may also differ in free-living and captive birds.

To the best of our knowledge, there are no other experimental studies in which females of sex-role-reversed bird species have been treated with testosterone. Goymann et al. (2008), however, showed that testosterone levels of territorially challenged females of the sex-role-reversed polyandrous Black Coucal (Centropus grillii) did not differ from those of unchallenged or non-territorial females, suggesting that female Black Coucals may secrete this hormone to a maximal level that cannot be further modulated during territorial challenges. If this were true for Barred Buttonquails as well, then an experimental elevation of testosterone possibly would not trigger a further increase in testosteronerelated traits because the hormone would already have been secreted to a maximal level and all receptors for the hormone would already have been bound. The regulation of testosterone-dependent behaviour may then rely entirely on the expression level of androgen receptors and/or the presence of androgen-binding proteins, or other factors involved in receptor regulation and hormone binding (Ball and Balthazart 2008).

Whether testosterone plays a role in other aspects of female-female competition or female-male interactions in Barred Buttonquails remains to be tested. A differential effect of testosterone during mating has been shown in male Frigatebirds, Fregata magnificens, in which testosterone activates courtship on the Lek, but not territorial behaviour (Chastel et al. 2005). In contrast, testosterone activates territorial behaviour, but not courtship, in male Sharp-tailed Grouse, Pedioecetes phasianellus, another lekking bird species (Trobec and Oring 1972). Female Barred Buttonquails develop a black throat patch, which differs between individual females in size and darkness (Muck and Goymann 2009). Both size and darkness of this throat patch 
correlate strongly with female plasma testosterone level, as do size and condition of the birds (Muck and Goymann 2009). While testosterone may not directly affect agonistic behaviour, the hormone may be indirectly responsible for the outcome of competitive interactions, e.g. females with larger and darker throat patches may be more competitive than smaller and more brightly coloured females (Amundsen 2000; Clutton-Brock 2009). Indeed, exogenous testosterone in female sex-role-reversed Wilson's Phalaropes led to the growth of nuptial plumage (Johns 1964); females of this species also show higher activity of enzymes responsible for the conversion of testosterone in the skin than males, which may account for the brighter plumage of females (Schlinger et al. 1989).

Alternatively, other hormones such as progesterone, dehydroepiandrosterone, or oestrogens could be involved in the regulation of female territorial aggression (Hau et al. 2004; Goymann et al. 2008; Pärn et al. 2008), as has been described for one sex-role-reversed species, the Black Coucal (Goymann et al. 2008). Further experimental studies that manipulate other hormones or block specific hormone receptors could show whether other steroids regulate male-like traits in female Barred Buttonquails. For now, the results of our study are either consistent with the view that changes in the circulating levels of testosterone do not alter the aggressive behaviour of female Barred Buttonquails, or show that our experimental setup using captive birds was not suitable for eliciting a strong territorial response to a simulated territorial intruder.

Acknowledgements Open access funding provided by Max Planck Society. This study was partially funded by a grant from the Deutsche Forschungsgemeinschaft (Go 985/5-1 and Go 985/5-2) to W. G. We thank Ingrid Schwabl and Monika Trappschuh for assistance with the hormone analysis. We also thank Andrea Peter, Sonja Bauer, Uli Gregori, and Gabi Haas for taking care of the birds used in this study, and Willi Jensen and Erich Koch for their technical support. We hereby confirm that the experiments carried out in this study comply with the current laws of Germany.

Open Access This article is distributed under the terms of the Creative Commons Attribution 4.0 International License (http://creativeco mmons.org/licenses/by/4.0/), which permits unrestricted use, distribution, and reproduction in any medium, provided you give appropriate credit to the original author(s) and the source, provide a link to the Creative Commons license, and indicate if changes were made.

\section{References}

Adkins-Regan E (1999) Testosterone increases singing and aggression but not male-typical sexual partner preference in early estrogen treated female Zebra Finches. Horm Behav 35:63-70

Amundsen T (2000) Why are female birds ornamented? Trends Ecol Evol 15:149-155
Andersson M (1995) Evolution of reversed sex roles, sexual size dimorphism and mating system in coucals (Centropodidae, Aves). Biol J Linn Soc 54:173-181

Apfelbeck B, Mortega KG, Kiefer S, Kipper S, Goymann W (2013) Life-history and hormonal control of aggression in Black Redstarts: blocking testosterone does not decrease territorial aggression, but changes the emphasis of vocal behaviours during simulated territorial intrusions. Front Zool 10:8

Araya-Ajoy YG, Dingemanse NJ (2013) Characterizing behavioural "characters": an evolutionary framework. Proc R Soc B Biol Sci 281:20132645

Arnold AP, Gorski RA (1984) Gonadal steroid induction of structural sex differences in the central nervous system. Ann Rev Neurosci $7: 413-442$

Ball GF, Balthazart J (2008) Individual variation and the endocrine regulation of behaviour and physiology in birds: a cellular/molecular perspective. Philos Trans R Soc B 363:1699-1710

Balthazart J (1983) Hormonal correlates of behaviour. In: Farner DS, King JR, Parkes CK (eds) Avian Biology, vol VII. Academic Press, London, pp 221-365

Canoine V, Gwinner E (2002) Seasonal differences in the hormonal control of territorial aggression in free-living European Stonechats. Horm Behav 41:1-8

Chastel O, Barbrauda C, Weimerskircha H, Lorméeb H, Lacroixa A, Tostain O (2005) High levels of LH and testosterone in a tropical seabird with an elaborate courtship display. Gen Comp Endocrin 140:33-40

Clutton-Brock T (2009) Sexual selection in females. Anim Behav $77: 3-11$

Clutton-Brock TH, Vincent ACJ (1991) Sexual selection and the potential reproductive rates of males and females. Nature 351:58-60

Debus SJS (1996) Turnicidae, buttonquail species accounts. In: Del Hoyo J, Elliott A, Sargatal J (eds) Handbook of the birds of the world, vol 3. Lynx, Barcelona, pp 44-59

Elekonich MM, Wingfield JC (2000) Seasonality and hormonal control of territorial aggression in female Song Sparrows (Passeriformes: emberizidae: Melospiza melodia). Ethology 106:493-510

Fivizzani AJ, Oring LW (1986) Plasma steroid hormones in relation to behavioural sex role reversal in the Spotted Sandpiper, Actitis macularia. Biol Reproduct 35:1195-1201

Fusani L (2008) Testosterone control of male courtship in birds. Horm Behav 54:227-233

Glickman SE, Caldwell GS (1994) Studying natural behaviour in artificial environments: the problem of 'salient elements'. In: Gibbons EF Jr, Wyers EJ, Waters E, Menzel EW Jr (eds) Naturalistic environments in captivity for animal behaviour research. SUNY, Albany, pp 197-216

Goymann W (2009) Social modulation of androgens in male birds. Gen Comp Endocrinol 163:149-157

Goymann W, Dávila PF (2017) Acute peaks of testosterone suppress paternal care: evidence from individual hormonal reaction norms. Proc R Soc B: Biol Sci 284:20170632

Goymann W, Wingfield JC (2004) Competing females and caring males. Sex steroids in African Black Coucals, Centropus grillii. Anim Behav 68:733-740

Goymann W, Wingfield JC (2014) Male-to-female testosterone ratios, dimorphism, and life history-what does it really tell us? Behav Ecol 25:685-699

Goymann W, Geue D, Schwabl I, Flinks H, Schmidl D, Schwabl H, Gwinner E (2006) Testosterone and corticosterone during the breeding cycle of equatorial and European Stonechats (Saxicola torquata axillaris and S. t. rubicola). Horm Behav 50:779-785

Goymann W, Wittenzellner A, Schwabl I, Makomba M (2008) Progesterone modulates aggression in sex-role reversed female African Black Coucals. Proc R Soc B 275:1053-1060 
Goymann W, Villavicencio CP, Apfelbeck B (2015) Does a short-term increase in testosterone affect the intensity or persistence of territorial aggression? An approach using an individual's hormonal reactive scope to study hormonal effects on behavior. Physiol Behav 149:310-316

Hau M, Stoddard ST, Somac KK (2004) Territorial aggression and hormones during the non-breeding season in a tropical bird. Horm Behav 45:40-49

Jawor JM, Young R, Ketterson ED (2006) Females competing to reproduce: dominance matters but testosterone may not. Horm Behav 49:362-368

Johns JE (1964) Testosterone-induced nuptial feathers in phalaropes. Condor 66:449-455

Ketterson ED, Nolan V Jr, Sandell M (2005) Testosterone in females: mediator of adaptive traits, constraint on sexual dimorphism, or both? Am Nat 166:85-98

McEwen BS, Davis PG, Parsons B, Pfaff DW (1979) The brain as a target for steroid hormone action. In: Cowan M (ed) Annual review of neuroscience, vol 2, pp 65-112

Muck C, Goymann W (2009) Throat patch size and darkness covaries with testosterone in females of a sex-role reversed species. Behav Ecol 20:1185-1193

Owens IPF (2002) Male-only care and classical polyandry in birds: phylogeny, ecology and sex differences in remating opportunities. Philos Trans R Soc B 357:283-293

Pärn H, Lindström KM, Sandell M, Amundsen T (2008) Female aggressive response and hormonal correlates-an intrusion experiment in a free-living passerine. Behav Ecol Sociobiol 62:1665-1677

Quispe R, Trappschuh M, Gahr M, Goymann W (2015) Towards more physiological manipulations of hormones in field studies: comparing the release dynamics of three kinds of testosterone implants, silastic tubing, time-release pellets and beeswax. Gen Comp Endocrinol 212:100-105

Ridley M (1978) Paternal care. Anim Behav 26:904-932

Rissman EE, Wingfield JC (1984) Hormonal correlates of polyandry in the Spotted Sandpiper, Actitis macularia. Gen Comp Endocrin 56:401-405

Rosvall KA (2013) Life history trade-offs and behavioral sensitivity to testosterone: an experimental test when female aggression and maternal care co-occur. PLOS ONE 8:e54120. https://doi. org/10.1371/journal.pone.0054120

Sandell MI (2007) Exogenous testosterone increases female aggression in the European Starling (Sturnus vulgaris). Behav Ecol Sociobiol 62:255-262

Schlinger BA, Fivizzani AJ, Callard GV (1989) Aromatase, $5 \alpha-$ and $5 \beta$-reductase in brain, pituitary and skin of the sex-role reversed Wilson's Phalarope. J Endocrin 122:573-581

Schwabl H, Flinksb H, Gwinner E (2005) Testosterone, reproductive stage, and territorial behavior of male and female European Stonechats Saxicola torquata. Horm Behav 47:503-512

Scriba M, Goymann W (2008) The decoy matters! Hormonal and behavioural differences in the reaction of territorial European Robins towards stuffed and live decoys. Gen Comp Endocrinol 155:511-516
Searcy WA (1988) Do female Red-winged Blackbirds limit their own breeding densities? Ecology 69:85-95

Soma KK (2006) Testosterone and aggression: Berthold, birds and beyond. J Neuroendocrin 18:543-551

Starck JM (1991) Biography and life history of Turnix suscitator Gmelin, 1789 - small adult body size as a consequence of selection for rapid growth. Z Zool Syst Evolut 29:213-237

Staub NL, DeBeer M (1997) The role of androgens in female vertebrates. Gen Comp Endocrinol 108:1-24

Sutter E (1955) Über die Mauser einiger Laufhühnchen und die Rassen von Turnix maculosa und sylvatica im indo-australischen Gebiet. Verhandl Naturforsch Ges Basel 66:86-139

Trobec RJ, Oring LW (1972) Effects of testosterone propionate implantation on lek behavior of Sharp-tailed Grouse. Am Midl Nat 87:531-536

Trollope J (1970) Behaviour notes on the Barred and Andalusian Hemipodes (Turnix suscitator and Turnix sylvatica). Avicult Mag 76:219-227

Veiga JP, Polo V (2008) Fitness consequences of increased testosterone levels in female Spotless Starlings. Am Nat 172:42-53

Voigt C (2016) Neuroendocrine correlates of sex-role reversal in Barred Buttonquails. Proc R Soc B 283:20161969

Voigt C, Goymann W (2007) Sex-role reversal is reflected in the brain of African Black Coucals (Centropus grillii). Dev Neurobiol 67:1560-1573

Wingfield JC (1985) Short-term changes in plasma levels of hormones during establishment and defense of a breeding territory in male Song Sparrows, Melospiza melodia. Horm Behav 19:174-187

Wingfield JC, Farner DS (1993) Endocrinology of reproduction in wild species. In: Farner DS, King J, Parkes K (eds) Avian biology. Academic Press, San Diego, pp 163-327

Wingfield JC, Wada M (1989) Changes in plasma levels of testosterone during male-male interactions in the Song Sparrow, Melospiza melodia. Time course and specificity of response. J Comp Physiol A 166:189-194

Wingfield JC, Jacobs JD, Tramontin AD, Perfito N, Meddle S, Maney DL, Soma K (2000) Toward an ecological basis of hormonebehavior interactions in reproduction of birds. In: Wallen K, Schneider J (eds) Reproduction in context. MIT Press, Cambridge, pp 85-128

Wingfield JC, Moore IT, Goymann W, Wacker D, Sperry T (2006) Contexts and ethology of vertebrate aggression: implications for the evolution of hormone-behavior interactions. In: Nelson R (ed) Biology of aggression. Oxford University Press, New York, pp 179-210

Zhao D, McBride D, Nandi S, McQueen HA, McGrew MJ, Hocking PM, Lewis PD, Sang HM, Clinto M (2010) Somatic sex identity is cell autonomous in the Chicken. Nature 464:237-242

Zysling DA, Greives TJ, Breuner CW, Casto JM, Demas GE, Ketterson ED (2006) Behavioral and physiological responses to experimentally elevated testosterone in female Dark-eyed Juncos (Junco hyemalis carolinensis). Horm Behav 50:200-207 